\title{
Scholars and Literati at the Gregorian University in Rome (1551-1773)
}

\author{
David de la Croix Soraya Karioun \\ IRES/LIDAM, UCLouvain
}

This note is a summary description of the set of scholars and literati who taught at the Jesuit University in Rome (Roman College - Gregorian University) from its inception in 1551 to the suppression of the Society of Jesus in 1773.

\section{The UnIVERSITY}

The first incarnation of this University, the Roman College (Collegio Romano) was founded by Ignatius of Loyola in 1551. It was one of the first and most important Jesuit colleges. Described as a school of grammar, humanities and Christian doctrine (Scuola di grammatica, d'umanità e di dottrina cristiana), the College was open to all and it provided general courses at no cost. Due to its erudite professors, the quality of its courses and its exceptional students, the College flourished and quickly outgrew its campus. In 1584 Pope Gregory XIII sought to enlarge the College and a permanent building was constructed. From there, with higher enrolment and an increase in the number of courses it offered, the Roman College matured as an institution of higher education. It was renamed the Gregorian University in honour of its generous benefactor. In the seventeenth century, the Gregorian University was the spearhead of the Counter-Reformation and the promoter of traditional Aristotelian science against the new approaches developed during the Scientific Revolution (Minois 2014). It ruled over all the hundreds of Jesuit high schools and universities worldwide. In 1773, the suppression of the Society of Jesus led to the closure of the University. The institution was re-established in 1824 by Pope Leo XII and remains under the direction of the Jesuits as the Pontifical Gregorian University (Grendler 2019).

\section{SOURCES}

This research is based on the work of the Spanish Jesuit historian, Riccardo Garcia Villoslada (1954). Between 1948 and 1975, this renowned professor and prolific writer taught modern history at the Pontifical Gregorian University. His book "Storia del Collegio Romano: dal suo inizio (1551) alla soppressione della Compagnie di Gesú (1773)" (1954) provides valuable information on the internal and external workings of the institution. It contains an appendix with an exhaustive list of all the professors who taught there. To complete our research, we have relied on an encyclopaedia of Jesuit Bibliography, "Bibliothèque de la Compagnie de Jésus" written by Carlos Sommervogel (1890).

\section{SOME STATISTICS}

Table 1 shows some descriptive statistics. There are 431 scholars and literati. The year of birth is known for $53.6 \%$ of them, which is a relatively high percentage (compared with the $26.1 \%$ known at another Jesuit university, Pont-a-Mousson, see De la Croix and Karioun (2021)). The mean age at appointment is 37.5 years, increasing over time. Expected age at death when 30 is 68 years. The birth place is known for $53.4 \%$ of the individuals, as we were able to match many of those in Villoslada (1954) with entries in biographical dictionaries. The median distance between place of birth and 
Rome is $304 \mathrm{~km}$. It is higher in the first period when the university drew people from further afield to staff its faculty and establish the College. The faculty remains international to the end, with median distance of $252 \mathrm{~km}$ for the last period. Finally, $13.9 \%$, of scholars have a Wikipedia page (in some language), while many of them (40.6\%) have left a footprint in the catalogues of the libraries of the world, Worldcat, either by having published some work, or by having been the subject of published books and articles. The difference between these two numbers reflects the fact that for Jesuits it was important to write and publish books, even for people who would remain quite obscure.

\begin{tabular}{|c|c|c|c|c|c|c|}
\hline \multicolumn{2}{|c|}{ Period } & $\mathrm{nb}$. & $\%$ birth year & mean age & mean age & exp. age \\
\hline Start & End & obs & known & at appoint. & at death & at death \\
\hline 1527 & 1617 & 158 & 50 & 34.1 & 65.4 & 65.4 \\
\hline 1618 & 1685 & 129 & 54.3 & 38.9 & 69.8 & 70.1 \\
\hline 1686 & 1733 & 82 & 58.5 & 39.4 & 67.4 & 67.5 \\
\hline 1734 & 1800 & 62 & 54.8 & 39.6 & 71.8 & 72.8 \\
\hline 1000 & 1800 & $\overline{4} 3 \overline{1}$ & $\overline{5} \overline{3} . \overline{6}$ & 37.5 & $\overline{6} \overline{8} . \overline{0}$ & 68.0 \\
\hline & & & $\begin{array}{c}\text { \% birth place } \\
\text { known }\end{array}$ & $\begin{array}{l}\text { median distance } \\
\text { birth-institution }\end{array}$ & $\begin{array}{c}\% \text { with } \\
\text { Wikipedia }\end{array}$ & $\begin{array}{c}\% \text { with } \\
\text { Worldcat }\end{array}$ \\
\hline 1527 & 1617 & & 48.7 & 427 & 20.3 & 41.8 \\
\hline 1618 & 1685 & & 57.4 & 276 & 13.2 & 43.4 \\
\hline 1686 & 1733 & & 57.3 & 231 & 3.7 & 40.2 \\
\hline 1734 & 1800 & & 51.6 & 252 & 12.9 & 32.3 \\
\hline 1000 & 1800 & & 53.4 & 304 & $13 . \overline{9}$ & 40.6 \\
\hline
\end{tabular}

Table 1: Summary statistics by period

\section{FIELDS}

Figure 1 shows the relative importance of fields, broadly defined. At its foundation, the Roman College scrupulously followed the Ratio studiorum, the fundamental curriculum of the Jesuit educational system. Several disciplines of the humanities were taught, such as Hebrew, Greek, and numerous chairs of philosophy. The Jesuits also taught sciences such as logic, mathematics, and astronomy. Finally, the College included many chairs of theology, such as sacred scripture, controversy, and scholasticism. In the Unknown category, we find the rectors and Prefecti studies, responsible for the proper dispensation of the Ratio studiorum. At the end of the 17th century, two new chairs appeared: ecclesiastical history and liturgy. These were not controversial, unlike the Chair of Canon Law, which faced a strong opposition from the University of Rome (Sapienza) and therefore could not be developed.

\section{Place of BIRTh}

Figure 2 is a plot of the places of birth of all the scholars of the Gregorian University. In the period 1537-1617, many scholars came from Spain. The "basin of attraction" is, not surprisingly, confined to the Catholic world but the university did attract talents from distant places.

\section{HUMAN CAPITAL OF SCHOLARS AND LITERATI}

For each person in the database we compute a heuristic human capital index, identified by combining information from Worldcat and Wikipedia using a principal component analysis. We also compute the notability of the university at each date by averaging the human capital of the scholars active 


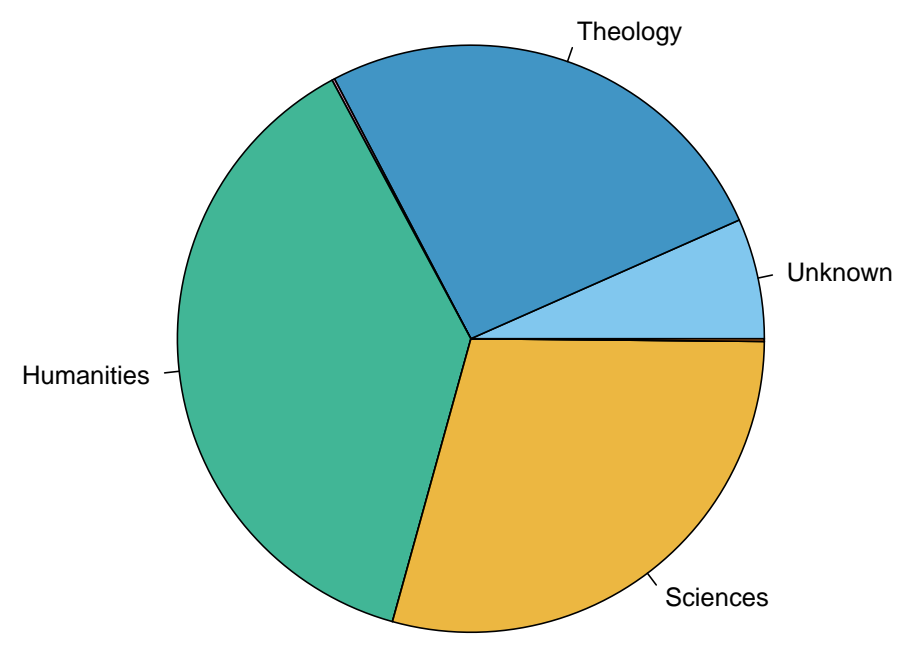

Figure 1: Broad fields at the Gregorian University

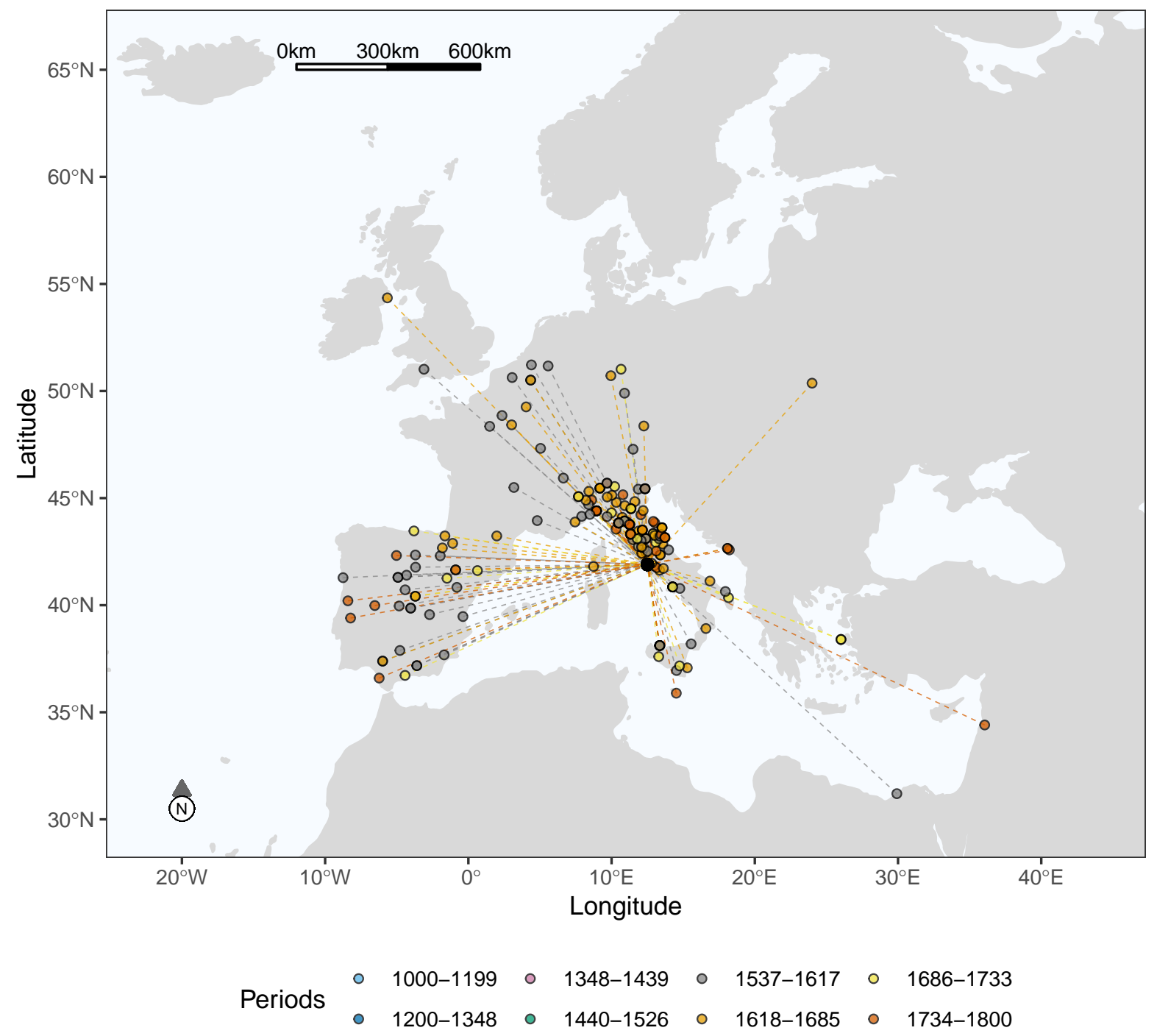

Figure 2: Place of birth of the scholars and literati at the Gregorian University 
at the Gregorian University 25 years before that date. Details are given in the Appendix. Figure 3 shows the names of all the scholars with a positive human capital index. The orange line plots the notability of the university. The vertical green lines (rug plot) show the distribution of all scholars, including the obscure ones, over time. The pattern indicates that the quality of the scholars and literati was high from the establishment of the University up until 1650. Then there is a slow decline with a final surge just before the Jesuits were expelled.

\section{TOP 6 PROFESSORS}

We provide a brief overview of the six professors with the highest human capital index.

Attanasio Kircher (1603 Geisa - 1680 Roma) entered the novitiate at the age of 14 and began teaching philosophy and mathematics in Würzburg in 1629. Driven out by the Thirty Years' War, he took refuge in France. He taught at the University of Avignon before being sent to Rome to teach mathematics, physics, and oriental languages. Considered one of the most remarkable Jesuits of his time, he distinguished himself by his important scientific contribution in a wide variety of fields: linguistics, Egyptology, geology, philology, mathematics, optics, and many other subjects. He was also known as a collector of antiquities and curiosities, which he housed in his own Museum, the Kircheriano.

Robertus Bellarminus (1542 Montepulciano - 1621 Roma) joined the Society of Jesus in 1560 and studied at the Roman College. He began teaching at the University of Louvain in 1570, and then returned to Rome, where he taught the art of controversy and held the position of rector. He dedicated himself to ecclesiastical functions from 1599 onwards. He was successively appointed Cardinal of Naples and Archbishop of Capua. This renowned figure had a role in the great issues of his time: he banned Galilee from teaching Copernicus' heliocentrism and participated at the trial of Giordano Bruno. Bellarminus' fame lasted beyond his death and reached its apogee between 1923 and 1931, when he was beatified, canonised and declared Doctor of the Church by Pope Pius XI, who had a great admiration for him.

Francisco Suarez (1528 Granada - 1617 Lisbon) is one of the most famous theologians and philosophers of his time. He was a leading figure in the Salamanca School. His scientific contribution is praised both for his exhaustive synthesis of the philosophy of the time and for his original ideas. He marked a historical turning point between classical scholasticism, represented by the Scotist and Thomistic heritage, and the beginning of modern philosophy. In addition to being a prolific author, Suarez was a dedicated professor. He taught theology and philosophy at the Roman College from 1580 to 1585, but also in Paris, Segovia, Valladolid, Alcala and Salamanca and for more than twenty years in Coimbra.

Ruggero Giuseppe Boscovich (1711 Dubrovnik - 1787 Milan) entered the novitiate in Rome in 1725. He pursued his education in Rome and was appointed professor of mathematics at the Gregorian University, a position he held for twenty years. Afterwards, he acquired a strong reputation for his many types of research in physics, astronomy, mathematics, and philosophy. He was received in several Academies, including the renowned Royal Society of London, and taught mathematics in a few other institutions, including the University of Pavia.

Christoph Clavius (1538 Bamberg - 1612 Roma), known as the Euclid of the 16th century, is one of the greatest mathematicians and astronomer of his time. He is credited with numerous works in astronomy, gnomonics (the design of sundials), geometry and mathematics, some of which are encyclopaedic works. He joined the Society of Jesus in 1555 and studied in Coimbra and at the Roman College, where he taught mathematics for more than twenty years. In 1579, Gregory XIII appointed him to continue the reform of the Julian calendar, the modifications of which led to the introduction of the Gregorian calendar, which is still in use today. 


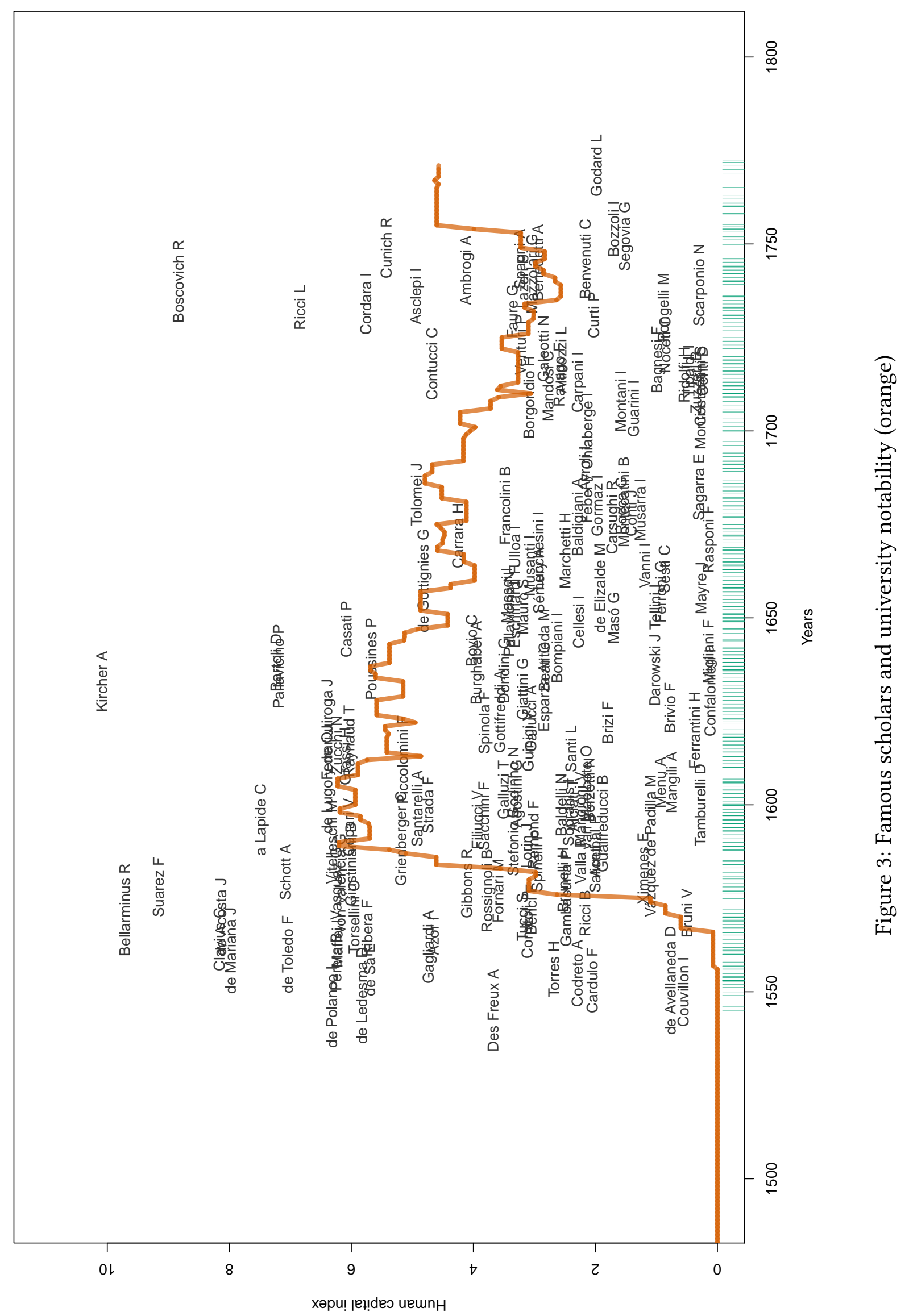


José de Acosta (1540 Medina-del-Campo - 1600 Salamanca) is a Spanish anthropologist and naturalist, mainly known for his missionary expedition to the West Indies. He joined the Society of Jesus at the age of twelve and was quickly recognised as having potential. He was appointed professor in several Spanish schools, notably in Ocaña, where he was the first Jesuit to teach theology. In 1594 he taught at the Roman College but returned to Spain a year later, where he held various positions, mainly at the professed house (residence in which Jesuits had a community life) of Valladolid and the University of Salamanca.

\section{UNIVERSITY NETWORK}

Here we assume that when a professor occupied a position at more than one university over his/her life, this established a link between those universities. The universities with which the Gregorian University is linked are displayed in Figure 4. Many links can be observed in all periods, as the Jesuits often reallocated their scholars among the numerous universities that they created in Europe. One should note the special relationship with Spain which lasted only during the first period.

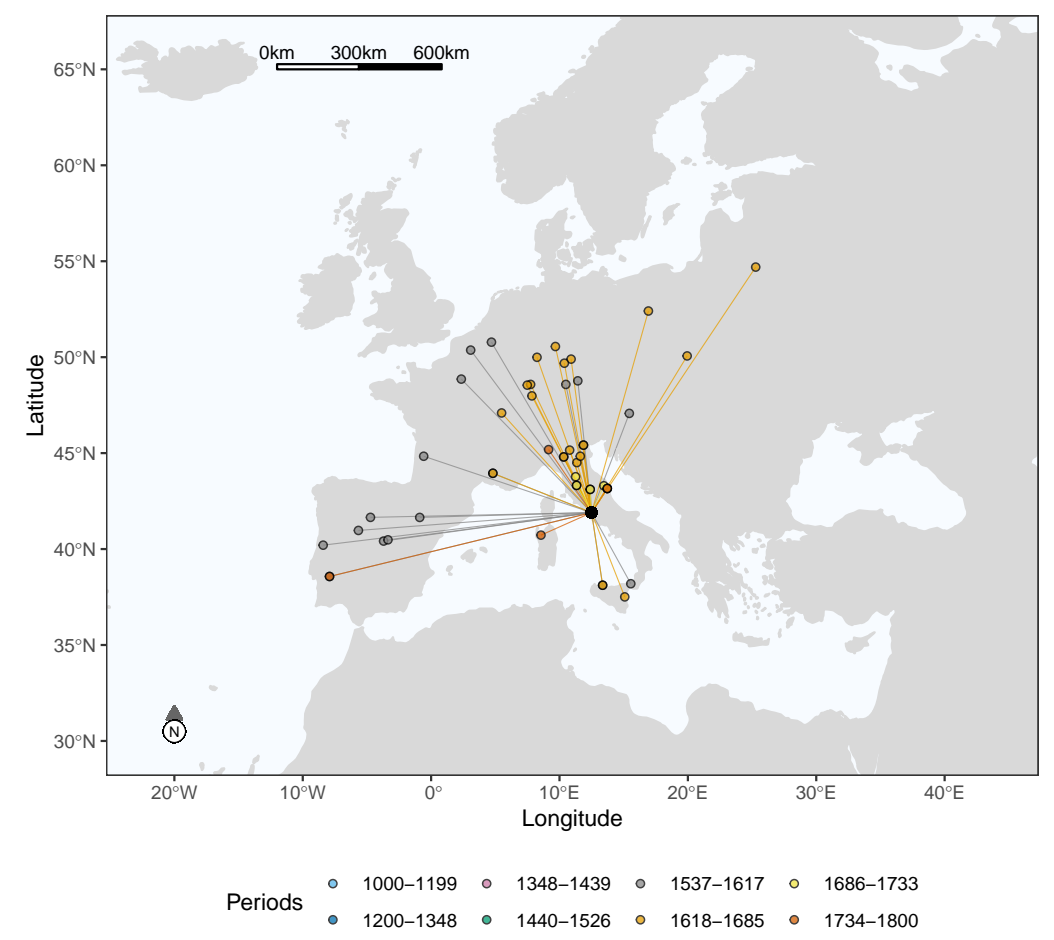

Figure 4: Links between the Gregorian University and other universities through scholars' mobility, by period

\section{CEnSORShip}

Among the 173 scholars who have published some work after 1400CE, 10 have been censored by the Catholic Church in its Index Librorum Prohibitorum (De Bujanda and Richter 2002). A rate of censorship of 6\% is about in line with Italy in general (Blasutto and De la Croix 2021). So being a Jesuit was no guarantee that one's writing would not be found to be heretical. Some examples are:

Juan de Mariana (Talavera-de-la-Reina 1536 - Toledo 1624, censored in 1628) was a Spanish priest, historian, and theologian. He was a professor of exegesis at the Roman College in Rome (from 1561) and of theology in Paris (1569). In his De monetae mutatione (part of the book Tractatus septem) he accused Philip III of starving the population via currency devaluation. This book was included in the index. 
Theophilus Raynaud (Sospel (F) 1587 - Lyon 1663, censored in 1658) was a French theologian and writer. He taught grammar and letters in Avignon, then philosophy and theology in Lyon and Rome. He joined the Society of Jesus in 1602. Several of his books were included in the index, including Erotemata and his De immunitatein which he criticized book censorship and the Dominicans' management of the Inquisition.

Achille Gagliardi (Padova 1537 - Modena 1607, censored in 1703) was a Jesuit theologian and spiritual writer. He taught philosophy at the Roman College, then theology in Padua and Milan. He was a collaborator of the Archbishop of Milan, Carlo Borromeo, who asked him to write a handbook of religion, the popular Catechismo della fede cattolica. His Breve compendio was censored because of his thoughts about the annihilation of the will during mystical states. These ideas are not compatible with free will, which is a cornerstone of Catholic theology.

\section{AnecDotes}

In his historical account of the fight led by the Jesuits against infinitesimal calculus, Alexander (2014) gives a central role to the Gregoriana. It reads like a novel: "On August 10, 1632, five men in flowing black robes (note: five Jesuits) convened in a somber Roman palazzo (note: the Gregoriana) to pass judgement on a deceptive simple proposition: that a continuous line is composed of distinct and infinitely tiny parts. With the stroke of a pen the Jesuit fathers banned the doctrine of infinitesimals, announcing that it could never be taught or even mentioned."

Two more anecdotes from Alexander (2014): When visiting the Gregoriana in 1581, the French writer Michel de Montaigne called the Jesuit order "a nursery of great men."

Whereas university students were free to indulge in a life of drunken debauchery (remember the writings of Villon and Rabelais), the students at the Gregoriana were closely supervised and filled their days with study and prayer.

\section{ApPENDIX}

The individual human capital index $q_{i}$ of an individual $i$ is given by:

$$
\begin{aligned}
q_{i}= & -1.76+0.43 \ln (\mathrm{nb} . \text { characters of the longest Wikipedia page }) \\
& +0.40 \ln (\mathrm{nb} . \text { Wikipedia pages in different languages })+0.47 \ln (\mathrm{nb} \text {. works in Worldcat }) \\
& +0.46 \ln (\mathrm{nb} . \text { publication languages in Worldcat })+0.47 \ln (\mathrm{nb} \text {. library holdings in Worldcat })
\end{aligned}
$$

We assume that having no Wikipedia page is similar to having one page with a length of 60 characters and that having no Worldcat page is similar to having a page with one work in one language held by one library. The constant -1.76 normalizes $q_{i}$ at 0 when there is neither a Wikipedia page, nor a Worldcat page. The weights $(0.43,0.40$, etc) are obtained from the first principal component of the five indicators (De la Croix et al. 2020).

The notability $Q$ of a university aggregates the $q$ of the top 5 persons who were active in the preceding 25 years using the following formula:

$$
Q=\sqrt{\sum_{i=1}^{5} \frac{1}{5}\left(\frac{q_{i}}{s_{i}}\right)^{2}}
$$

where $s_{i}$ is the number of universities in which $i$ had an appointment.

\section{ACKNOWLEDGMENTS}

This project has received funding from the European Research Council (ERC) under the European Union's Horizon 2020 research and innovation programme, under grant agreement No 883033 "Did elite human capital trigger the rise of the West? Insights from a new database of European scholars."

First version March 19, 2021. Updated November 25, 2021. 


\section{REFERENCES}

Alexander, Amir. 2014. Infinitesimal: How a dangerous mathematical theory shaped the modern world. New York: Macmillan.

Blasutto, Fabio, and David De la Croix. 2021. "Catholic Censorship and the Demise of Knowledge Production in Early Modern Italy.” CEPR Discussion Paper 16409.

De la Croix, David, Frédéric Docquier, Alice Fabre, and Robert Stelter. 2020. "The Academic Market and the Rise of Universities in Medieval and Early Modern Europe (1000-1800)." CEPR Discussion Paper 14509.

De la Croix, David, and Soraya Karioun. 2021. "Scholars and Literati at the University of Pont-àMousson (1572-1768)." Repertorium eruditorum totius Europae 2:1-6.

De Bujanda, Jésus Martínez, and Marcella Richter. 2002. Index des livres interdits: Index librorum prohibitorum. Montréal: Médiaspaul.

Grendler, Paul F. 2019. Jesuit Schools and Universities in Europe 1548-1773. Brill Research Perspectives in Jesuit Studies. Leiden: Brill.

Minois, Georges. 2014. L'Eglise et la science: Histoire d'un malentendu. De saint Augustin à Galilée. Paris: Fayard.

Sommervogel, Carlos. 1890. Bibliothèque de la Compagnie de fésus. Brussels: Oscar Schepens.

Villoslada, Ricardo García. 1954. Storia del Collegio Romano dal suo inizio (1551) alla soppressione della Compagnia di Gesù (1773). Rome: Gregorian Biblical BookShop. 